\title{
Study on the extraction of metals from tails of flotation enrichment of copper sulfide ores
}

\author{
(C) Vladimir V. Musayev, ${ }^{*}$ Anton M. Klyushnikov ${ }^{+}$and Ramil R. Galimov \\ Laboratory of Hydrometallurgy. JSC Uralmekhanobr (UMMC-Holding Corp.). Khokhryakov St., 87. \\ Ekaterinburg, 620144. Russia.Phone:+7 (343) 344-27-42.E-mail:klyushnikov_am@umbr.ru
}

\begin{abstract}
*Supervising author; ${ }^{+}$Corresponding author
Keywords: tailings, flotation, roasting, leaching, gold, copper.
\end{abstract}

\section{Abstract}

Flotation processing of copper-pyrite ores is accompanied by the formation of flotation tailings containing $0.2-$ $0.7 \% \mathrm{wt} \mathrm{Cu}$ and $0.6-1.4 \mathrm{~g} / \mathrm{t} \mathrm{Au}$. Deeper extraction of these components into commercial products is of practical interest. The possibility of additional recovery of copper and gold using the example of tailings from the current processing of PJSC "Gaysky GOK" was studied. It was shown that thin emulsion impregnation of chalcopyrite (less than $10 \mu$ ) in pyrite prevented the copper and gold from being extracted from the tailings by ore dressing methods. A scheme for the deep extraction of valuable components, based on the preliminary concentration of gold and copper by pyrite flotation, was proposed. About $84.5 \%$ of gold and $60.9 \%$ of copper were extracted into pyrite concentrate, while the gold content in the chamber product was $0.25 \mathrm{~g} / \mathrm{t}$. The increase in the extraction of copper was impossible due to nature of copper phase in chamber product that consisted mainly of copper oxides. Further processing of the pyrite concentrate can be accomplished by the way based on oxidative roasting $\left(550-600{ }^{\circ} \mathrm{C}\right)$, with subsequent sulfuric acid leaching of copper from the calcine, washing and cyanidation of washed cake. Acid leaching is recommended to be done without external heating with solutions of $10-20 \mathrm{~g} / 1$ of sulfuric acid. Copper was precipitated from leachates by cementation with iron powder in the form of copper concentrate $(22-32 \% \mathrm{wt} \mathrm{Cu})$, then the gold-containing solution is processed to produce ligature gold. The optimal conditions for the cyanidation of the calcine were determined as follows, $\mathrm{L}: \mathrm{S}=2$, the initial concentration of $\mathrm{NaCN}$ was $2 \mathrm{~g} / \mathrm{l}$, the duration of cyanidation was 2 hours The possibility of achieving end-to-end extraction of $66 \%$ of gold, and $45 \%$ of copper in commercial products is shown. The proposed scheme makes it possible to reduce the specific consumption of $\mathrm{NaCN}$ during cyanidation from $2.5-2.8$ to $0.8 \mathrm{~kg} / \mathrm{t}$ of tailings. It is assumed to gain sulfuric acid from the burning gases.

\section{References}

[1] V.A. Bocharov, V.A. Ignatkina, E.L. Chanturia. Main directions of solving the problems of complex processing of pyrite tails of copper-zinc ore flotation. Non-ferrous metals. 2011. No.12. P.20-26. (russian)

[2] Technology of enrichment of copper and copper-zinc ores of the Urals. Ed. by V. A. Chanturiya, I. V. Shadrunova. Moscow: Science. 2016. 387p. (russian)

[3] D.S. Reutov, B.D. Halezov. The search for optimal conditions for sulfuric acid leaching to recover copper and zinc from flotation tailings copper slag. Butlerov Communications. 2015. Vol.44. No12. P.199-203. DOI: 10.37952/ROI-jbc-01/15-44-12-199

[4] Y.F. Sergeeva, S.V. Mamyachenkov, V.A. Sergeev, N.R. Gallyamova. The modern methods of processing dust copper-smelter enterprises. Butlerov Communications. 2012. Vol.30. No5. P.1-19. ROI: jbc-02/12-30-5-1

[5] V.V. Lodejshchikov. Technology for extracting gold and silver from refractory ores. Vol.1. Irkutsk: Irgiredmet. 1999. 342p. (russian)

[6] Fazlullin M.I. Heap leaching of precious metals. Moscow: Publishing House of the Academy of Mining Sciences. 2001. 647p. (russian)

[7] V.I. Smirnov, A.I. Tikhonov. Roasting of copper ores and concentrates (theory and practice). Sverdlovsk: Metallurgizdat. 1966. 255p. (russian)

[8] I.G. Reznitsky, N.P. Dobroselskaya. Production of sulfuric acid from waste gases of non-ferrous metallurgy. Moscow: High School. 1980. 245p. (russian)

[9] V.I. Zelenov. Methods of research of gold ore. Moscow: Nedra. 1989. 302p. (russian)

[10] D.S. Reutov, B.D. Khalezov, L.A. Ovchinnikova, and A.S. Gavrilov. Study of the speed of dissolution of copper and zinc ferrite by the rotating disc method. Butlerov Communications. 2018. Vol.54. No.5. P.5662. DOI: $10.37952 /$ ROI-jbc-01/18-54-5-56 